\title{
MEDIA SOSIAL, DEMOKRASI, DAN PENYAMPAIAN PENDAPAT POLITIK MILENIAL DI ERA PASCA-REFORMASI
}

\author{
Rahkasiwi Dimas Susanto ${ }^{1}$, Irwansyah ${ }^{2}$ \\ ${ }^{1}$ Universitas Pelita Harapan \\ Email: rahka.lioe@gmail.com \\ ${ }^{2}$ Universitas Indonesia \\ Email: dr.irwansyah.ma@gmail.com
}

\begin{abstract}
ABSTRAK
Milenial di Indonesia merupakan generasi yang tumbuh pada era pasca-reformasi dan kemajuan teknologi. Hadirnya media sosial sebagai jaringan sosial yang digandrungi generasi milenial di Indonesia menciptakan budaya dan kultur baru di tengah-tengah masyarakat. Dalam Demokrasi budaya dan kebebasan dalam menyampaikan pendapat menjadi faktor penting. Dengan menggunakan metodologi fenomenologi, penelitian ini akan memahami bagaimana peran media sosial, dan kebebasan dalam mengemukakan pendapat pada generasi milenial. Termasuk juga mengunggap tren baru di mana media sosial telah menjadi medium dalam menyampaikan aspirasi maupun suara publik dewasa ini.

Kata Kunci: Media Sosial, Kebebasan Berpendapat, Milenial
\end{abstract}

\begin{abstract}
Millennials in Indonesia are a generation that grew up in the post-reform era and technological advancements. The presence of social media as a social network that is loved by millennials in Indonesia creates a new culture and culture in the midst of society. In a democracy culture and freedom of speech are important factors. By using phenomenological methodology, this study will understand the role of social media, and freedom in expressing opinions to millennials. This includes bucking a new trend in which social media has become a medium for conveying public voices and aspirations nowdays.

Keyword: Social Media, Freedom of Speech, Millennials
\end{abstract}

\section{PENDAHULUAN}

Mengemukakan pendapat dan demokrasi menjadi dua sisi mata uang yang saling mempengaruhi. Hal ini tidak lepas dari semangat demokrasi yang dipaparkan Abraham Lincoln yakni "dari rakyat, oleh rakyat, dan untuk rakyat." Gagasan ini bukan menjadi isapan jempol belaka, Watkins dan Stratenus menyebut keleluasaan dalam mengemukakan pendapat sebagai bagian dari demokrasi itu sendiri, gagasan ini dikembangkan dalam istilah Crowdocracy,

Crowdocracy is a linguistic blend of crowd and democracy. It builds on the philosophy of direct democracy and many recent experiment such as citizen assemblies and crowdsourcing legislation as well as many other emergent decision-making models that seek to put power directly in the hands of the people. (Watkins \& Stratenus, 2016, h.2)

Kebebasan dalam mengemukakan pendapat politik dalam ranah demokrasi menjadi hal krusial, bahkan tak jarang kebebasan berpendapat menjadi produk dari demokrasi itu sendiri. Memasuki abad 21, terdapat ragam sarana agar masyarakat dapat mengemukakan pendapat. Mulai dari keterwakilan secara sistem politik melalui Dewan Perwakilan Rakyat dan Dewan Perwakilan Daerah, berdemonstrasi, pers, hingga mengemukakan pendapat melalui jejaring sosial. Hadirnya media sosial menyugguhkan sarana baru bagi masyarakat untuk mengemukakan pendapat secara lebih luas. Seiring perkembangannya, media sosial bukan lagi menjadi sarana sebatas jejaring pertemanan, namun sudah berubah sebagai medium untuk mengemukakan pendapat. (Arsyad \& Nadjib, 2011) Pada 2020, Indonesia memiliki sekitar 65,7\% pengguna aktif media sosial di 
Indonesia berada pada rentan usia 18 hingga 34 tahun dari total 272,1 juta jiwa populasi. (Katadata.co.id, 2020) Data tersebut menyebutkan bahwa pengguna aktif media sosial di Indonesia didominasi oleh generasi milenial.

Milenial sebagai bagian dari masyarakat memiliki karakteristiknya sendiri, hidup dalam perkembangan teknologi, Fatmawati (2020, h.1) dalam jurnalnya berjudul Kebebasan Informasi 'Kalangan Milenial dalam Bermedia Sosial' menyebut “Internet bagi kalangan milenial sudah tidak terpisahkan lagi. Internet tidak hanya hadir untuk mengakomodir kebutuhannya akan informasi tetapi juga menjadi ruang interaksi sosial yang lebih besar."

Sebagai generasi yang menikmati kemudahan akses informasi dan teknologi, penelitian ini akan menggali bagaimana generasi milenial mampu memanfaatkan media sosial sebagai sarana untuk mengemukakan pendapat dalam mendukung kebebasan berekspresi di ranah demokrasi.

\section{Signifikansi}

Dengan menyoroti media sosial dan budaya generasi milenial untuk mengemukakan pendapat di era pasca-reformasi, penelitian ini diharapkan mampu menambah khazanah literatur terkait studi Komunikasi, Masyarakat dan Tekonologi. Penelitian ini juga akan menggali budaya masyarakat berjaring (network society) dengan iklim demokrasi yang ada di Indonesia.

\section{TINJAUAN PUSTAKA Media Sosial}

Media sosial adalah platform berbasis digital yang memberikan ruang bagi penggunanya untuk mengemukakan pendapat maupun pemikirannya, melalui media sosial penggunanya dapat bertukar informasi. (Harahap \& Adeni, 2020) Pada 2020, pengguna media sosial di Indonesia sekitar 59\% dari 272,1 juta jiwa populasi, atau sekitar 160 juta penduduk Indonesia merupakan pengguna media sosial aktif. Dalam sehari rata-rata pengguna media sosial di Indonesia menghabiskan lebih dari 3 jam untuk berselancar di ragam platform media sosial. (Kemp, 2020) Berdasarkan usia, di tahun 2020 mayoritas pengguna media sosial di Indonesia berada pada usia 25 hingga 34 tahun dengan presentase 35,4 persen dari populasi. Disusul masyarakat dengan usia 18 hingga 24 tahun sebagai pengguna media sosial aktif dengan presentase 30,3\%. (Katadata.co.id, 2020)

Perkembangan media sosial tidak lepas dari penetrasi penggunaan Internet di Indonesia, Survei yang dilakukan oleh Asosiasi Penyelenggara Jasa Internet menyebut penetrasi pengguna internet di Indonesia mencapai $73,7 \%$ dengan pertumbuhan pengguna internet mencapai $8,9 \%$. Hingga saat ini pulau jawa masih menjadi konsumen pengguna internet terbesar di Indonesia dengan tingkat penetrasi internet mencapai 56,4\% dari seluruh pengguna Internet di Indonesia. (APJII, 2020) Dalam perkembangannya terdapat tren penggunaan media sosial di Indonesia berkembang dalam ragam kegunaan. Mulawarman dan Nurfitri (2017) dalam jurnalnya berjudul "Perilaku Pengguna Media Sosial beserta Implikasinya Ditinjau dari Perspektif Psikologi Sosial Terapan” memaparkan sejumlah tren penggunaan media sosial di Indonesia;

1) Selfie atau Swafoto, media sosial berkembang menjadi wadah untuk menunjukan foto diri sebagai wujud eksistensi dan aktualisasi penggunanya. Swafoto yang diunggah juga dapat menjadi wujud dari keterbukaan-diri dari pengguna jejaring sosial.

2) Perang Siber atau Cyberwar, kebebasan dalam mengemukakan pendapat antar pengguna media sosial acap kali menimbulkan perdebatan dan selisih paham. Dalam kasus Pilpres 2014 misalnya, Perang Siber untuk adu argumen antar pengguna media sosial tercipta berdasarkan perbedaan pandangan politik.

3) Belanja Online, media sosial juga menjadi tempat bagi UMKM untuk mengembangkan bisnis dan transaksi perniagaan. Facebook menjadi salah satu platform media sosial yang mengembangkan fitur belanja online untuk penggunanya. 
4) Pengembangan Identitas dan Citra Diri, media sosial telah menghadirkan tren baru bagi penggunanya untuk mengembangkan citra diri di ranah digital sekaligus mengembangkan identitas diri sesuai preferensi yang mereka inginkan.

Di sisi lain, tren yang berkembang di media sosial dewasa ini adalah munculnya ragam informasi palsu atau hoaks, ujaran kebencian, hingga konten-konten intoleransi. Munculnya konten-konten negatif tersebut tidak lepas dari ketidakmampuan pengguna media sosial dalam memaknai kebebasan berbicara di ranah digital. (Masril \& Lubis, 2020) Hal ini yang membuat penggunaan media sosial dalam beberapa waktu terakhir menjadi sorotan serius terkait etika dan adab dalam mengemukakan pendapat. Survei Microsoft menyebut indeks kesopanan netizen Indonesia di ranah digital paling rendah. Dalam surveinya ini menyebut Indonesia berada diposisi 29 dari 32 negara yang disurvei. (Microsoft, 2021)

Sementara, di ranah politik, media sosial juga menjadi media baru dalam meraih suara khususnya pemilih muda. Media sosial dewasa ini juga dijadikan sarana untuk membuat penggunanya terliterasi secara politik. (Tarsidi et al., 2019) Gencarnya literasi politik di ranah media sosial juga melahirkan fenomena buzzer politik. Istilah buzzer pada awalnya kerap digunakan dalam istilah pemasaran, namun sejak pemilu 2014, buzzer di ranah politik menjadi tren dalam berkampanye di media sosial. Politisi menggunakan jasa buzzer untuk membentuk opini masyarakat hingga meningkatkan elektabilitas mereka. (Felicia \& Loisa, 2019)

\section{Demokrasi dan Kebebasan Mengemukakan Pendapat di Indonesia}

Sejak merdeka pada 1945, Indonesia menganut sistem demokrasi dalam kehidupan berbangsa dan bernegara. Secara harafiyah demokrasi berasal dari dua kata yakni 'demos' dan 'kratos'. Dalam bahasa Yunani, dua kata tadi bermakna sebagai sebuah sistem pemerintahan dari, untuk dan oleh rakyat. Untuk memahami demokrasi secara lebih dalam Wahyudi (2005, h.24) mendeskripsikan jika,

Demokrasi dinilai sesuai dengan tuntutan-tuntutan kebutuhan "non-material" manusia. Nilai-nilai demokrasi akan dapat memanusiakan manusia, sebab nilai-nilainya bertitik tolak dari nilai-nilai luhur. Anggapan ini muncul karena beberapa faktor, diantaranya penderitaan manusia akibat fasisme, totaliterianisme, komunisme, dan paham-paham antidemokrasi lainnya.

Penjabaran itu mengambarkan bahwa demokrasi adalah kebutuhan fundamental dalam kehidupan berbangsa dan bernegara. Kebebasan dalam demokrasi juga dianggap sebagai kebutuhan mendasar.

Sejak era kolonialisme upaya untuk menyatakan pendapat dalam sebuah situasi politik tidaklah mudah. (Yacob \& Syam, 2016) Kebebasan mengemukakan pendapat saat itu yang diwakili dengan hadirnya media menjadi ancaman bagi pemerintah Hindia-Belanda. Aturan pers di Hindia-Belanda telah menjadi senjata untuk mengekang kebebasan berpendapat melalui pers dengan cara menindak siapa saja yang melontarkan kritik terhadap pemerintah kolonial. (Yuliati, 2018)

Memasuki masa awal Kemerdekaan, kebebasan dalam mengemukakan pendapat juga masih sulit diwujudkan. Purnaweni (2004, h.120) menyebut,

Soekarno mencoba sistem Demokrasi Terpimpin, yang katanya menjadi demokrasi khas Indonesia. Sekalipun Soekarno mengatakan bahwa pemerintahannya menganut sistem demokrasi, namun praktik yang meluas dalam kehidupan bangsa dan negara justru adalah kekuasaan yang serba terpusat (sentralistik) pada diri Soekarno. Bung Karno selaku Presiden bahkan memperagakan pemerintahan diktator dengan membubarkan Konstituante, PSI, dan Masyumi serta meminggirkan lawan-lawan politiknya yang kritis.

Pergantian rezim yang berkuasa dan Orde Lama menuju Orde Baru tidak pun tidak membawa banyak perubahan. Di masa Soeharto, kondisi demokrasi Indonesia dibuat menjadi kekuasaan tunggal. Soeharto membuat Golongan Karya atau Golkar sebagai kendaraan baru dalam 
menguasai politik. Golkar yang selalu ada dalam posisi teratas dalam sejumlah hasil Pemilihan Umum, telah membuat sentra kekuasaan pada era itu berada tangan Soeharto. Ia telah menjadi pusat dari kekuasaan itu sendiri melalui rangkap jabatan yang ia emban, yakni sebagai Presiden, sebagai Pimpinan Golkar yang menguasai parlemen, hingga Presiden sebagai panglima tertinggi di dalam sistem militer. (Purnaweni, 2004; Wahyudi, 2005)

Keran kebebasan dalam beraspirasi mulai terbuka seiring runtuhnya pengaruh kekuasaan Soeharto dan rezim orde barunya. Pada medio 1998, orde baru tumbang dan digantikan dengan semangat baru bernama era 'reformasi'. Pada masa ini kebebasan dan hak untuk menyampaikan aspirasi dilindungi oleh Undang-Undang No. 9 tahun 1998 tentang Kebebasan Menyampaikan Pendapat di Muka Umum. (H. P. Nugroho, 2015) Kebebasan itu juga yang melahirkan sebuah budaya baru dalam berdemokrasi dan melahirkan kultur baru dalam mengemukakan pendapat. 23 tahun sudah budaya berdemokrasi dan kebebasan mengemukakan pendapat di Indonesia berkembang sejak era reformasi. Meski demikian berdasarkan survei Indikator Politik pada 24-30 September 2020 sebanyak $21,9 \%$ responden menyatakan sangat setuju jika masyarakat Indonesia makin takut untuk mengemukakan pendapat. Survei ini diambil dari sekitar responden 1.200 orang yang dipilih secara acak, dengan margin of error sekitar 2,9\% dan tingkat kepercayaan 95\%. (Detik.com, 2020) Hasil suvei tersebut menjadi menjadi alarm dari upaya menciptakan demokrasi partisipatoris di Indonesia. Suvei tersebut juga mencatat sebanyak 53\% responden menyatakan agak setuju, sementara 20,8\% sangat setuju jika masyarakat cenderung sulit untuk berdemonstrasi.

\section{Milenial}

Milenial atau generasi Y merupakan sebuah istilah yang dikembangkan oleh dua pakar sejarah dan penulis Amerika, William Strauss dan Neil Howe dalam beberapa bukunya. Penggolongan generasi ini digolongkan bagi kelompok masyarakat yang lahir pada medio akhir 1980 hingga awal 2000. (Republika.co.id, 2016) Sementara menurut Smith dan Nichols dalam jurnalnya Understanding the Millennials Generation (2015, h.39) menyebut,

The most recent generation to enter the workforce are the Millennials, who are individuals born between 1980 and 2000. They are called Millennials because of their closeness to the new millennium and being raised in a more digital age. This generation was influenced by computers and a greater acceptance of non-traditional families and values.

Lebih lanjut, Smith dan Nichols (2015) menjabarkan Generasi milenial senang memanfaatkan teknologi. Generasi Milenial menjadi tergantung pada teknologi pada usia yang lebih awal dibandingkan generasi lainnya. Selain itu generasi milenial juga senang menemukan hal baru, seperti belajar bahasa baru, orang-orang yang memanfaatkan teknologi pada usia dini menjadi lebih mahir daripada orang-orang yang belajar di kemudian hari dalam hidup mereka. Diduga semakin banyak generasi Milenial yang mulai mengambil alih tempat kerja, maka teknologi yang lebih terintegrasi akan dalam proses kerja.

Di ranah digital, pesatnya penetrasi internet di seluruh dunia tidak lepas dari kehadiran generasi milenial. Iklim berinternet yang menjunjung tinggi kebebasan telah menjadi sarana bagi generasi milenial dalam berekspresi. (Sari, 2019) Kebebasan ini juga yang tercermin dalam pandangan milenial terhadap politik. Generasi milenial mengakualisasikan ekspresi berpolitik melalui semangat kebebasan dalam mengemukakan pendapat. Meski tingkat partisipasi milenial rendah secara kuantitas, namun secara kualitas, generasi milenial mampu menuangkan gagasangagasan mereka di ranah politik dengan menggunakan platform digital. (Wirawan \& Yuliartini, 2018) 


\section{METODE PENELITIAN \\ Metodologi Penelitian}

Penelitian ini menggunakan metodologi Fenomenologi dengan paradigma Kualitatif. Metodologi Fenomenologi pertama kali dikenalkan oleh Edmund Husserl dan kemudian dikembangkan dalam sebuah penelitian sosial. Dalam prosesnya Fenomenologi melingkupi proses pengamatan dan membiarkan sebuah fenomena muncul. (Kuswarno, 2009) Rahardjo menyebut,

Peneliti fenomenologis berusaha untuk memahami makna peristiwa atau gejala serta interaksi pada orang atau sekelompok orang dalam situasi tertentu. Karena fenomenologi berada di bawah payung paradigma interpretif, maka pendekatan ini menghendaki adanya sejumlah asumsi yang berlainan dengan cara yang digunakan paradigma positivistik yakni dengan menemukan "fakta" atau "penyebab" suatu peristiwa. (2018, h.2)

Sehingga penelitian ini akan melihat bagaimana sebuah fenomena pada generasi milenial dalam memanfaatkan media sosial sebagai cara untuk mengemukakan pendapat terkait isu-isu politik di Indonesia. Sementara paradigma kualtitatif digunakan untuk mendeskripsikan, dan menganalisa sebuah fenomena yang terjadi di masyarakat. Setiap permasalahan-permasalahan yang muncul dalam proses penelitian ini dibiarkan terbuka untuk kemudian diinterpretasikan.

Data yang dikembangkan dalam metode Fenomenologi akan menjadi data primer dalam penelitian ini. Sementara data sekunder dalam penelitian ini akan menggunakan analisa dokumen dari penelitian yang pernah ada pada penelitian-penelitian yang pernah ada sebelumnya.

Proses Wawancara dilakukan selama 29 Maret hingga 25 April 2021, pertanyaan yang diajukan terkait alasan bermedia sosial, aktivitas harian dalam bermedia sosial, hingga pemaknaan berekspresi dalam menggunakan media sosial.

\section{Unit Analisa dan Sumber Data}

Unit analisa dalam penelitian ini adalah individu dengan metode pengumpulan data yakni wawancara dan observasi sebagai sumber data primer, dan menganalisa dokumen sebagai sumber data sekunder. Data yang diolah dalam penelitian ini meliputi proses wawancara dari sejumlah informan. Dalam memilih informan, peneliti memilih informan berdasarkan sejumlah kriteria yakni; (1) Informan merupakan generasi milenial, (2) Informan aktif dalam menggunakan media sosial dan membahas ragam isu di Indonesia, (3) Informan memahami perkembangan dan isu politik yang berkembang di Indonesia.

Sumber data yang peneliti miliki berjumlah tiga informan. Informan pertama bernama Syarifah Hafiyah Yahya merupakan perempuan kelahiran tahun 1990, Saat ini ia bekerja sebagai seorang Jurnalis di salah satu Televisi Swasta di Indonesia, dan sudah berkarir selama 9 tahun sebagai reporter dan Produser untuk ragam informasi terkait Politik, Hukum, dan Keamanan. Hafiyah sudah menjadi pengguna media sosial aktif sejak 2009. Informan kedua adalah Aisha Miadinar. Lahir pada 1989, perempuan yang berdomisili di Jakarta ini menjadi pengguna aktif media sosial sejak 2004. Saat ini, Aisha sudah lebih dari 9 tahun bekerja sebagai Jurnalis untuk isu seputar Politik, Hukum, dan Keamanan. Informan ketiga adalah Yeni Agustina, milenial kelahiran 1991 ini sejak 2008 sudah aktif menggunakan media sosial dalam kehidupan sehari-hari. Yeni sendiri berprofesi sebagai jurnalis untuk media berbasis politik dan hukum.

Sementara untuk data sekunder dalam penelitian ini, peneliti mengkaji dari sejumlah literatur berupa penelitian-penelitian yang sudah ada sebelumnya untuk memperkuat hasil penelitian yang sudah ada.

\section{Validitas Data}

Dalam penelitian ini, proses pengumpulan data melalui wawancara, observasi, dan analisa dokumen akan dilakukan uji validitas dengan menggunakan metode triangulasi data. Menurut Bachri (2010, h.55) "triangulasi adalah suatu pendekatan analisa data dari berbagai sumber". Triangulasi juga digunakan untuk menguji data yang ada guna memperkuat penjelasan dalam 
penelitian. Dalam proses triangulasi data, penganalisaan mengacu pada sumber informasi dengan menggolongkan sejumlah informasi/data untuk membandingkan dan menemukan data jenuh dalam sebuah penelitian.

\section{HASIL PENELITIAN}

Berdasarkan hasil wawancara dan obervasi, sebagian besar informan dalam penelitian ini merupakan pengguna aktif yang sudah cukup lama menggunakan media sosial. Rata-rata sudah lebih dari 10 tahun aktif menggunakan media sosial. Pada medio awal menggunakan media sosial, sejumlah informan menyebutkan alasan masing-masing dalam bergabung dan menggunakan media sosial.

"Saya menggunakan media sosial sebagai media untuk menyambung silaturahmi dengan kawan dan keluarga, berbagi momen, juga untuk mengupdate sejumlah informasi dari dalam dan luar negeri." (Hafiyah)

"Awalnya saya mengikuti tren di lingkungan dalam menggunakan media sosial, istilahnya ikut-ikutan teman untuk berbagi informasi. Mulai dari bergossip hingga aktivitas lainnya. Belakangan saya menggunakan media sosial untuk mencari informasi seputar apa yang tejadi di dalam dan luar negeri." (Aisha)

"Awalnya pake media sosial karena kepo, penasaran lah. Soalnya orang-orang di sekitarku udah banyak yang pakai media sosial, jadi pengen ikutan pake juga. Lama kelamaan pakai media sosial buat dapetin banyak informasi yang dibutuhin dalam kehidupan sehari-hari. Mulai dari isu parenting, perkembangan berita, sampe apa yang jadi pembahasan di linimasa." (Yeni)

Berdasarkan hasil wawancara tersebut, dapat disimpulkan pada tahap awal, para informan menggunakan media sosial sebagai bagian dari tren sosial yang ada di masyarakat. Umumnya mereka menggunakan media sosial karena lingkungan di sekitar juga menggunakan media sosial sebagai sarana dalam berkomunikasi dan bertukar informasi. Hal ini diperkuat dengan hasil penelitian dari Rafiq (2020, h.27) yang menyebut "Dengan hadirnya medsos (media sosial) sebagai teknologi baru, tentu saja cara hidup manusia juga akan mengalami perubahan. Beberapa perubahan adalah semakin efektif dan efisiennya manusia dalam memperoleh informasi tidak terhalang waktu, tempat dan biaya yang tidak terlalu mahal."

Berdasarkan uraian di atas, media sosial sudah menjadi medium baru sebagai kegiatan untuk berkomunikasi dan juga menjadi kegiatan untuk mencari informasi soal apa yang terjadi di sekitar. Media sosial sudah menjadikan penggunanya seolah hidup dalam sebuah "negara, kawasan, ataupun desa" yang tidak lagi merasakan dampak batas-batas wilayah atau bentang geografis. Karena para penggunanya membagikan dan memperoleh informasi secara lebih mudah.

Terdapat ragam informasi yang setiap harinya dibagikan oleh para pengguna media sosial, mulai dari aktivitas harian, pemikiran-pemikiran, hingga pembahasan terkait sejumlah isu.

"Hampir satu sampai dua tahun terakhir sering berbagi di media sosial terkait banyak isu. Tapi rata-rata curhahan hati soal kebijakan pemerintah. Mulai dari penanganan Covid-19 sampai isu soal kebakaran hutan misalnya. Tapi belakangan lebih sering re-post statusstatus orang." (Hafiyah)

"Ya sehari bisa share banyak postingan. Kira-kira bisa 10 kali lah sehari, rata-rata ya. Itu diawal pakai media sosial. Sekarang cenderung lebih jarang. Di awal-awal sih posting soal hal remeh-temeh, soal galau-galau soal percintaan, atau sekedar info terkini cuaca. Tapi sekarang lebih ke informasi soal parenting sampai isu-isu yang hangat menjadi perbincangan di masyarakat. Sekarang cenderung lebih berhati-hati sih untuk share sesuatu terutama soal politik, soalnya males juga timbul missed perception atau kegaduhan di linimasa" (Aisha) 
"Waktu SMA mostly konten yang dishare lebih ke galau-galauan. Misalnya status soal ngincer ke orang yang disuka, pacar-pacaran. Nah pas kuliah masih sedikit galau-galau, tapi mulai bahas pemikiran-pemikiran kritis soal kuliah dan isu-isu nasional. Nah pas kuliah itu mulai kenal forum-forum yang lebih luas. Kalo sekarang kontennya cenderung lebih ke isuisu terkini, misalnya soal politik, parenting, atau soal bisnis. Bahkan dipakai buat jualan produk." (Yeni)

Berdasarkan keterangan para informan, umumnya pengguna media sosial cenderung berubah di awal penggunaan dalam proses bertukar informasi. Sebagian besar pada tahap awal penggunaanya para informan cenderung membagikan sejumlah topik-topik yang bersifat lebih personal. Misalnya curahan hati, atau apa yang mereka lakukan di dalam kehidupan sehari-hari. Namun seiring berkembangnya penggunaan media sosial, para penggunanya cenderung menaruh perhatian pada isu-isu terkini yang terjadi di masyarakat. Termasuk sejumlah isu terkait politik, hukum, dan keamanan. Dalam pembahasan tersebut dapat kaji bahwa setiap informan kini makin menyadari bahwa media sosial sebagai ranah publik untuk bertukar gagasan dan informasi, sehingga bukan lagi sekedar platform untuk bertukar informasi pribadi. Dalam risetnya berjudul "Evaluasi Pemanfaatan Media Sosial sebagai Sarana Knowledge Sharing", Assegaff (2017) menjabarkan peran media sosial sebagai sarana untuk penggunanya dalam mendapatkan informasi dan berbagi informasi. Kepuasan dalam memperoleh informasi juga menjadikan media sosial sebagai kebutuhan dalam berinterkasi untuk bertukar pengetahuan.

Informan cenderung menggunakan media sosial sebagai platform untuk mengemukakan pendapat termasuk untuk isu-isu terkait politik. Mereka merasa ada keleluasaan dalam mengemukakan pendapat secara bebas dan egaliter.

"Alasan Media sosial jadi salah satu tempat mengemukakan pendapat karena bisa menjangkau lebih banyak orang dan praktis, bisa share informasi dan berita terkini. Apalagi Media sosial ada di HP, jadi praktis banget. Dan murah juga, Cuma modal paket data." (Hafiyah)

"Aku merasa lebih bebas sih ya dan nyaman untuk mengemukakan pendapat di media sosial. Mungkin karena media sosial ga ada batasan-batasan yang jelas. Jadi ada kebebasan berpendapat disitu. Kalaupun ada batasan, sifatnya hanya Undang-Undang ITE yang sifatnya pasal karet." (Aisha)

"Menurutku media sosial mempermudah pemakainya untuk dapat mengemukakan pendapat. Ada perasaan bahwa apa yang kita posting dibaca dan direspon. Biarpun kadang positif, kadang juga negative ya. Tapi respon itu merasa kita didengar. Seperti ngasih insight tersendiri buat kita. Ada perasaan lega setelah mengeluarkan pendapat lewat media sosial. Kalo dibanding yang lain sebenernya media sosial emang lebih gampang sih, karena tinggal buka HP, ketik-ketik, kemudian pendapat kita sampai deh ke timeline, syukur-syukur kalo jadi pembahasan dan trending topic" (Yeni)

Pemaparan sejumlah informan sejalan dengan penelitian yang berjudul "Perubahan dan Permasalahan Media Sosial”, penelitian tersebut memaparkan perubahan sosio-kultural terhadap budaya bermedia seiring lahirnya budaya new-media di tengah kehidupan sehari-hari. Jika sebelumnya media konvensional seperti televisi, radio hingga surat kabar bersifat satu arah. Hadirnya media sosial sebagai new-media mengubah bagaimana perilaku masyarakat dalam memandang peran media. Melalui peran media sosial, seseorang dapat membentuk sebuah jaringan virtual, saling mengungkapkan pendapat, hingga berinteraksi satu sama lain. (Anwar, 2017)

Di sisi lain, masing-masing informan cenderung memilih media sosial untuk membahas atau menyoroti sebuah isu politik, di banding mengemukakan pada kolom-kolom pembaca di media massa maupun menyampaikan aspirasi melalui keterwakilan Anggota DPR.

"Media sosial itu lebih nyaman dipilih dibandingkan menyampaikan suara melalui media massa, soalnya sekarang media massa juga berasosiasi dengan kepentingan politik tertentu. 
Kebijakan redaksional diatur, ada yang boleh ditampilkan, ada yang tidak boleh ditampilkan. Semua konten disortir sesuai kebutuhan dan kepentingan media itu sendiri. Sementara menyampaikan aspirasi melalui anggota DPR itu melelahkan, menghabiskan energy dan waktu. Termasuk juga saat berdemonstrasi. Jadi peran media digital dalam menyampaikan pendapat dan aspirasi tidak terelakan." (Hafiyah)

"Lebih percaya bisa menyampaikan pendapat melalui kanal digital. Kalo lewat DPR ga percaya bakalan menampung aspirasi. Karena banyak kasus anggota DPR pun pada akhirnya mengkhianati rakyat. Ga mampu mendengarkan aspirasi rakyat. Sementara kalo ke Media Massa suka diplintir. Kalo Media sosial cenderung aman sih, meski netizen suka mentafsirkan yang melenceng dari konteks, tapi pesan kita tersampaikan secara utuh." (Aisha)

"Kalo dibilang lewat media sosial lebih praktis sih. Utamanya aspirasiku soal ruang public ya. Kayak contohnya soal isy transportasi umum, kayak bus transjakarta. Kalo aspirasi lewat media massa cenderung rumit dan lama juga. Malah sekarang media massa banyak ambil topik-topik dari Media sosial. Apa yang ada di timeline kayak mewakili keinginan publik." (Yeni)

Berdasarkan hasil wawancara tersebut, Media sosial menjadi instrument baru dalam menyampaikan pendapat. Jika sebelumnya cara mengemukakan pendapat dalam sebuah sistem demokrasi dapat dilakukan dengan cara keterwakilan di parlemen (Anggota DPR), berdemonstrasi, atau melalui Media Massa yang mewakili kepentingan publik. Namun bagi generasi milenial, Media sosial menjadi pilihan yang paling mudah dan cepat dalam mengemukakan suatu pendapat di ranah publik. Hal ini tidak lepas dari hilangnya citra keterwakilan rakyat yang direpresentasikan oleh DPR, hingga citra media massa yang cenderung sarat kepentingan dan tidak mampu memberikan gambaran utuh tentang aspirasi publik. Sementara melalui media sosial, setiap konten yang disampaikan pengguna bersifat utuh sesuai dengan kehendak penggunanya. Setiap pengguna media sosial tidak lagi khawatir jika pendapatnya kemudian disunting atau diubah sesuai kepentingan tertentu.

Di sisi lain, hadirnya media sosial tidak lepas dari perkembangan teknologi seluler. Peranti binerak atau mobile device adalah jenis perangkat lunak yang memungkinkan pengguna untuk melakukan tugas tertentu yang dapat diinstal dan berjalan pada berbagai perangkat digital portabel seperti smartphone dan tablet. (Liu et al., 2014) Ponsel yang berada dalam saku ataupun genggaman manusia menjadi sarana yang paling mudah diakses untuk berbagai kegiatan. Hadirnya aplikasi media sosial dalam ponsel ataupun peranti mobile turut mempermudah siapa saja dalam mengakses medium utuk berkomunikasi. Revolusi dari perkembangan perangkat mobile telah terjadi di dalam kehidupan sehari-hari. Orang-orang bergerak cepat dari ponsel biasa ke ponsel pintar, baik di negara maju maupun negara berkembang. Akses seluler ke sumber daya berjaringan meresap ke semua aspek kehidupan sehari-hari dan telah mengubah ekspektasi orang akan kemudahan akses. (Wong, 2012) Termasuk akses untuk dapat mengemukakan pendapat terkait isu-isu publik dengan lebih mudah.

Hal ini juga yang tergambarkan dari hasil observasi di media sosial terkait sejumlah isu politik, hukum, dan keamanan. Seperti kasus penyiraman air keras kepada Penyidik KPK, Novel Baswedan. Ketika Majelis Hakim menuntut dua pelaku penyiraman, Rahmat Kadir Mahulette dan Ronny Bugis, dengan pidana satu tahun penjara. Warganet ramai-ramai menyoroti hal tersebut. Keyword 'Novel Baswedan' menjadi trending topic di media sosial Twitter pada 11 Juni 2020. Hal ini menunjukan peran media sosial sebagai medium paling diminati saat ini untuk menyampaikan pandangan dan kritik pada isu-isu politik, hukum, dan keamanan. Saud dkk. (2020, h.93) dalam penelitiannya Media Sosial dan Digitalisasi Partisipasi Politik pada Generasi Muda: Perspektif Indonesia menyebut "Usia antara 18 hingga 22 tahun, sebagian besar aktif dan terlibat dengan politik domestik mereka, di mana itu menandakan indikator positif bagi potensi partisipasi politik 
kaum muda." Hasil penelitian tersebut mengambarkan bagaimana milenial memiliki partisipasi aktif dalam menggunakan media sosial dan mengemukakan pendapat terkait isu politik.

Meski demikian, Para Informan menyoroti munculnya pasal karet dalam Undang-Undang Informasi dan Transaksi Eelektronik (UU ITE) yang dapat mengikis kebebasan dan budaya bebas berpendapat di media sosial.

"Saya rasa UU ITE jelas mengancam. UU ITE kan awalnya dibuat untuk menjerat pelaku penipuan siber, tapi malah justru digunakan untuk menjerat individu-individu yang berpendapat di media sosial, dan hanya berdasarkan laporan dari orang lain." (Hafiyah)

"Adanya UU ITE ini jadi muncul ketakutan untuk mengemukakan pendapat di media sosial. Tapi sebenernya UU ITE bisa diakalin dengan pintar-pintar dalam menyuarakan opini, misalnya ga sebut nama, ga deskriptif dan lain-lain." (Aisha)

"Sebenernya serba susah ya, kadang kebebasan berpendapat emang perlu. Tapi kalo bablas dan cenderung berkomentar tanpa mempertimbangkan nilai-nilai moral, etika, dan adab dalam bekomunikasi, itu ga bisa dibenarkan juga. Tapi kalo UU ITE digunakan juga untuk memidanakan orang-orang yang kritis juga ga bisa dibenarkan. Impelementasi UU ITE jadi tanggung jawab bersama sih, Netizen juga harus cerdas, dan penegak hukum ga bisa serampangan dalam menindak sebuah aduan terkait UU ITE. Jangan sampai hanya karena aduan pasal-pasal karet, kebebasan berpendapat jadi terdampak." (Yeni)

Permasalahan terkait UU ITE yang menjadi momok bagi kebebasan berpendapat dan berdemokrasi di Indonesia menjadi perhatian serius. Hal ini juga yang menjadi guyonan satir milenial di media sosial terkait isu terorisme yang menyasar milenial. Hal ini menyeruak ketika pemerintah merilis potensi milenial yang tidak memiliki pemikiran kritis mudah sekali tersusupi paham terorisme. (Kompas.com, 2021a) Namun isu itu dibuat menjadi lelucon oleh warganet dengan mencuitkan "Tidak berpikir krtitis jadi teroris. Berpikir Kritis, kena UU ITE."

Guyon satir milenial di media sosial bukan tak berdasar. Undang-Undang ITE terdapat kausal yang tidak memberikan deskripsi rinci dan memunculkan multitafsir mengenai hak dan keleluasaan dalam menyampaikan pendapat di ranah digital. Salah satu pasal yang disoroti ialah pasal 27 ayat (3) UU ITE. Pasal ini kerap kali dijadikan sebagai upaya untuk menjerat seseorang ataupun sekelompok orang ke ranah hukum dengan detil mencemarkan nama baik. (Notanubun, 2014; A. S. Nugroho, 2010) Atmaja, dkk. (2020, h.140) mendeskripsikan

Pasal 27 Ayat (3) juncto Pasal 45 Ayat (1) UU ITE dinilai oleh para pegiat hak asasi manusia sebagai Pasal karet yang rentan disalahgunakan penguasa. Pasal 27 Ayat (3) juncto Pasal 45 Ayat (1) UU ITE dikatakan sebagai kelanjutan dari Kitab Undang-Undang Hukum Pidana (KUHP) sebab pasal tersebut merujuk pada ketentuan Bab XVI Buku II KUHP tentang penghinaan yang termuat dalam Pasal 310 dan 311 KUHP. Mengenai delik yang termaktub dalam Pasal 27 Ayat (3) dan Pasal 28 Ayat (2) UU ITE, mekanisme kriminalisasi seharusnya diubah karena delik yang dikualifikasikan sejatinya bukan delik biasa. Penyelesaian sengketa di luar pengadilan mesti diutamakan.

Pada akhirnya hadirnya UU ITE di tengah arus digitalisasi kerap dianggap sebagai upaya untuk memberangus kebebasan dalam menyampaikan aspirasi. Pasal karet dalam UU ITE juga membuat sejumlah nama seperti Ahmad Dhani, Jerinx, hingga Gus Nur harus terjerat kasus hukum dengan alasan melanggar UU ITE.

Fenomena bahwa UU ITE dapat mengancam kebebasan berpendapat dan mengikis nilainilai demokrasi sudah disadari oleh Presiden Joko Widodo. Untuk itu Presiden sebagai kepala negara meminta aparat hukum tidak lebih cermat dalam memproses laporan hukum terkait pelanggaran UU ITE. (Tempo.co, 2021) Pemerintah pun tengah megkaji kemungkinan untuk merevisi sejumlah pasal karet dalam UU ITE. (Kompas.com, 2021b) 


\section{SOCIAL CONSTRUCTION OF TECHNOLOGY (SCOT) DAN MEDIA SOSIAL BAGI MILENIAL}

Berdasarkan hasil penelitian di atas, peneliti menemukan adanya dialektika simultan antara pengguna dan media sosial itu sendiri. Hal ini terlihat dari bagaimana awalnya pengguna media sosial menggunakan platform tersebut hanya sebagai jejaring sosial dalam berkomunikasi, namun lambat laun berkembang dan digunakan sebagai sarana dalam menerima informasi, menyampaikan gagasan, hingga menyuarakan gagasan dalam berpolitik.

Kemunculan teknologi sebagai alat untuk mempermudah kerja manusia telah berdampak pada budaya di dalam kehidupan sehari-hari. Termasuk hadirnya media sosial dalam berkomunikasi. Media sosial sebagai jejaring sosial telah menghapus sekat-sekat yang membatasi komunikasi mulai dari kendala geografis hingga retang waktu pengiriman pesan. Hadirnya berbagai teknologi komunikasi telah menciptakan generasi milenial yang ada saat ini sebagai sebuah struktur masyarakat yang terbentuk akibat hadirnya teknologi komunikasi, hal ini juga yang disebut sebagai masyarakat informasi. Dalam struktur masyarakat ini, sebuah informasi didistribuskan dan dapat diakses bagi setiap individu. (Isazadeh, 2004)

Dalam hasil penelitian di atas, terdapat sebuah fenomena menarik, di mana pengguna media sosial mampu mendeterminasi fungsi dan kegunaan teknologi digital sesuai dengan kebutuhannya. Jika pada tahap awal penggunaan media sosial, para informan cenderung memakainya sebagai tempat untuk berinteraksi dalam lingkup pertemanan, namun seiring berjalannya waktu, media sosial telah berfungsi sebagai wadah untuk mengemukakan pendapat dan sarana dalam menyampaikan aspirasi dan kritik terhadap topik-topik politik.

Kondisi di mana pengguna media sosial dapat mendeterminasi sebuah teknologi sesuai kebutuhannya merupakan penerapan dari teori Social Construction of Technology.

Klein \& Kleinman (2002, h.29) menerjemahkan Konstruksi Sosial tehadap teknologi sebagai "suggests that technology design is an open process that can produce different outcomes depending on the social circumstances of development."

Determinasi penggunana media sosial yang terjadi telah melahirkan budaya baru dalam memanfaatkan teknologi di masyarakat. Dalam hal ini teknologi tidak lagi dipandang dapat membentuk struktur masyarakat, namun masyarakat memiliki pilihan dalam menggunakan teknologi. Octavianto (2014, h.55-56) menjabarkan,

Seseorang atau sekelompok orang akan menempatkan diri baik secara sadar maupun tidak pada posisi tertentu terhadap penggunaan media sosial. Penempatan posisi demikian ini akan tergantung pada interpretasi makna yang dibangun terhadap media sosial dan fungsinya bagi orang itu. Interpretasi pada awalnya berkesan bebas, namun sesungguhnya dibentuk berdasarkan struktur makna yang mewadahi praktik-praktik penggunaan media sosial tersebut.

Sehingga bagaimana pengalaman setiap informan dalam menggunakan media sosial sebagai medium dalam mengemukakan pendapat telah menjadi pewujudan dari teori Social Construction of Technology.

\section{PENUTUP \\ Kesimpulan}

Dalam perkembangannya media sosial telah menjadi tren baru bagi masayrakat Indonesia khususnya generasi milenial dalam menyuarakan aspirasi mereka di ranah politik. Media Sosial dipandang sebagai sarana paling efektif dan praktis dalam upaya menyampaikan gagasan dan pandang hingga mengkritisi sebuah kebijakan pemerintah.

Hal ini tidak lepas dari kemudahan platform media sosial yang dapat diakses melalui peranti seluler. Jika pada medio awal penggunaan media sosial adalah wahana jejaring sosial semata, namun media sosial juga digunakan sebagai medium dalam berdemokrasi. Pengguna mendeterminasi penggunaan sebuah teknologi untuk menunjang kebutuhan hariannya. 
Kehadiran media sosial di sebagai ranah dalam berdemokrasi telah menjadi budaya baru dalam pendistribusian gagasan atau pemikiran rakyat. Bahkan melalui media sosial juga, sebuah gagasan tidak lagi terkendala lokasi geografis.

\section{Saran}

Penggunaan media sosial dalam mengemukakan pendapat menjadi gambaran dari iklim demokrasi yang ideal. Namun jika munculnya pasal-pasal karet dalam sistem hukum di Indonesia kemudian menciptakan ketakutan dan memukul mundur budaya kebebasan berpendapat di Indonesia.

Setiap pembuat kebijakan perlu memberikan perhatian dalam memastikan setiap regulasi yang ada tidak mengikis ataupun menjadi kontra-produktif dalam mewujudkan iklim demokrasi di Indoensia. Adanya regulasi yang menjadi ketakutan bagi masyarakat dalam berpendapat bebas di media sosial perlu dikaji secara komperhensif, sehingga tidak menimbulkan perspektif publik bahwa sebuah regulasi bersifat represif.

Milenial sebagai generasi yang tidak tumbuh dalam lingkup pemerintahan yang represif di masa orde lama dan orde baru menjadi pionir untuk dapat mendorong generasi baru yang lebih kritis dan menghargai kebebasan dalam mengemukakan pendapat.

\section{DAFTAR ISI}

Anwar, F. (2017). Perubahan dan Permasalahan Media Sosial. Jurnal Muara Ilmu Sosial, Humaniora, Dan Seni, 1(1), 137. https://doi.org/10.24912/jmishumsen.v1i1.343

APJII. (2020). Laporan Survei Internet APJII 2019 - 2020. Asosiasi Penyelenggara Jasa Internet Indonesia, 2020, 1-146. https://apjii.or.id/survei

Arsyad, R. M., \& Nadjib, M. (2011). PADA MEDIA JEJARING SOSIAL Analisis Wacana Facebook Dari Jejaring Pertemanan Menuju Jejaring Perlawanan. Jurnal Komunikasi KAREBA, 1(1), 77-83.

Assegaff, S. (2017). Evaluasi Pemanfaatan Media Sosial sebagai Sarana Knowledge Sharing. Jurnal Manajemen Teknologi, 16(3), 271-293. https://doi.org/10.12695/jmt.2017.16.3.4

Atmaja, Y., Mulyani, T., \& Sihotang, A. (2020). Analisis Yuridis Mengenai Hak Mengeluarkan Pendapat Dalam Perspektif HAM. 53(9), 1689-1699.

Azharini, E. (2019). Fenomenologi. https://doi.org/10.31227/osf.io/j9r86

Bachri, B. S. (2010). Meyakinkan Validitas Data Melalui Triangulasi Pada Penelitian Kualitatif. Teknologi Pendidikan, 10, 46-62.

Detik.com. (2020). Survei Indikator: Mayoritas Responden Takut Nyatakan Pendapat Saat Ini. https://news.detik.com/berita/d-5228103/survei-indikator-mayoritas-responden-takutnyatakan-pendapat-saat-ini

Fatmawati, E. (2020). Kebebasan Informasi Kalangan Milenial Dalam Ber-media Sosial. JPUA: Jurnal Perpustakaan Universitas Airlangga: Media Informasi Dan Komunikasi Kepustakawanan, 10(2), 94. https://doi.org/10.20473/jpua.v10i2.2020.94-103

Felicia, F., \& Loisa, R. (2019). Peran Buzzer Politik dalam Aktivitas Kampanye di Media Sosial Twitter. Koneksi, 2(2), 352. https://doi.org/10.24912/kn.v2i2.3906

Harahap, M. A., \& Adeni, S. (2020). Tren penggunaan media sosial selama pandemi di indonesia. Jurnal Professional FIS UNIVED, 7(2), 13-23.

Isazadeh, A. (2004). Information society: concepts and definitions. WSEAS Transactions on Systems, $3(6), 2407-2410$.

Katadata.co.id. (2020). Berapa Usia Mayoritas Pengguna Media Sosial di Indonesia? https://databoks.katadata.co.id/datapublish/2020/11/23/berapa-usia-mayoritas-penggunamedia-sosial-di-indonesia

Klien, H. K., \& Kleinman, D. L. (2002). The Social Construction of Technology: Structural Considerations.

Kompas.com. (2021a). Mahfud MD dan BNPT Pernah Ingatkan Ancaman Teroris Milenial, Jumlahnya 
Ribuan. https://nasional.kompas.com/read/2021/04/01/11164461/mahfud-md-dan-bnptpernah-ingatkan-ancaman-teroris-milenial-jumlahnya-ribuan?page=all

Kompas.com. (2021b). Revisi UU ITE, Berawal dari Keresahan Jokowi namun Batal Masuk Prolegnas Prioritas 2021. https://nasional.kompas.com/read/2021/03/12/20521121/revisi-uu-iteberawal-dari-keresahan-jokowi-namun-batal-masuk-prolegnas?page=all

Kuswarno, E. (2009). Metodelogi Penelitian Komunikasi Fenomenologi: KOnsepsi, Pedoman dan Contoh Penelitian. 56, VIII + 264.

Masril, M., \& Lubis, F. W. (2020). Analisis Penggunaan Media Sosial dan Penyebaran Hoax Di Kota Medan. JURNAL SIMBOLIKA: Research and Learning in Communication Study, 6(1), 11-22. https://doi.org/10.31289/simbollika.v6i1.2937

Microsoft. (2021). Digital Civility 2021 Global Report. https://www.microsoft.com/en-us/digitalskills/digital-civility?activetab=dci_reports\%3Aprimaryr4

Mulawarman, M., \& Nurfitri, A. D. (2017). Perilaku Pengguna Media Sosial beserta Implikasinya Ditinjau dari Perspektif Psikologi Sosial Terapan. Buletin Psikologi, 25(1), 36-44. https://doi.org/10.22146/buletinpsikologi.22759

Notanubun, P. G. (2014). Tinjauan Yuridis Terhadap Kebebasan Berbicara Dalam Ketentuan Pasal 27 Ayat 3 UU Nomor 11 Tahun 2008 Tentang ITE Dalam Hubungan Dengan Pasal 28 UUD 1945. Jurnal Ilmu Hukum, 12(2), 112.

Nugroho, A. S. (2010). Perlindungan Kebebasan Berpendapat Melalui Media Internet Dalam Undang-Undang No.11 Tahun 2008 Tentang Informasi dan Transaksi Elektronik Dijuntau dari Perspektif Hak Asasi Manusia. In Universitas Sebelas Maret Surakarta (Vol. 9, Issue 1).

Nugroho, H. P. (2015). Politik Hukum HAM Pasca Orde Baru (Studi Tentang Kebebasan Berpendapat). http://weekly.cnbnews.com/news/article.html?no=124000

Octavianto, A. W. (2014). Strukturasi Giddens dan Social Construction of Technology (SCoT) Sebagai Pisau Analisis Alternatif Penelitian Sosial Atas Teknologi Media Baru. Jurnal ULTIMA Comm, 6(2), 41-57. https://doi.org/10.31937/ultimacomm.v6i2.417

Purnaweni, O. H. (2004). Demokrasi Indonesia: Dari Masa Ke Masa. Jurnal Administrasi Publik, 3(2), $118-131$.

Rafiq, A. (2020). Dampak Media Sosial Terhadap Perubahan Sosial Suatu Masyarakat. Global Komunika, 1(1), 18-29.

Republika.co.id. (2016). Mengenal Generasi Millennial. https://www.republika.co.id/berita/koran/inovasi/16/12/26/ois64613-mengenal-generasimillennial

Sari, S. (2019). Literasi Media Pada Generasi Milenial Di Era Digital. Profesional: Jurnal Komunikasi Dan Administrasi Publik, 6(2), 30-42. https://doi.org/10.37676/professional.v6i2.943

Saud, M., Ida, R., Abbas, A., Ahmad, R., \& Ashfaq, A. (2020). Media Sosial dan Digitalisasi Partisipasi Politik pada Generasi Muda : Perspektif Indonesia. 8(1), 87-97.

Smith, T. J., \& Nichols, T. (2015). Understanding the Millennial Generation. Journal of Financial Service Professionals, 69(6), 11-14.

http://eds.a.ebscohost.com.laureatech.idm.oclc.org/eds/pdfviewer/pdfviewer?sid=0a0336d0 -b8da-410d-a5b3-7e42fa4cbe86@sessionmgr4004\&vid=1\&hid=4210

Tarsidi, D. Z., Nugraha, I. S., Fadhilah, F., \& Pertiwi, G. (2019). Orientasi "Poligami” (Politik Generasi Millenial) Dalam Mengahadapi Pesta Demokrasi 2019. Prosiding Seminar Nasional \& Call Paper Psikologi Sosial 2019 PSIKOLOGI SOSIAL DI ERA REVOLUSI INDUSTRI 4.0: PELUANG \& TANTANGAN Fakultas Pendidikan Psikologi, 59-65.

Tempo.co. (2021). Jokowi Minta Polisi Tak Serampangan Gunakan UU ITE. https://nasional.tempo.co/read/1433219/jokowi-minta-polisi-tak-serampangan-gunakanuu-ite

Wahyudi, L. (2005). Demokrasi Orde Baru.

Watkins, A., \& Stratenus, I. (2016). Crowdocracy; The End of Politics. Urbane Publications. 
Wirawan, I. G. M. A. S., \& Yuliartini, N. P. R. (2018). Ekspresi Politik Generasi Millenial Pada Pilgub Bali Tahun 2018. Prosiding Seminar Nasional Hukum Dan Ilmu Sosial, 2, 170-182. https://pdfs.semanticscholar.org/2815/5d9ca4a914b3aea6accdbdd2599c80950962.pdf

Yacob, D. W. U., \& Syam, F. (2016). Gerakan Politik Tirto Adhi Soerjo. Jurnal Politik Universitas Nasional, 12(1), 1749-1756.

Yuliati, D. (2018). Pers, Peraturan Negara, dan Nasionalisme Indonesia. Anuva, 2(3), 253. https://doi.org/10.14710/anuva.2.3.253-272 